\title{
Potential of thyme essential oil on arugula sanitization
}

\section{Potencial do óleo essencial de tomilho na sanitização de rúcula}

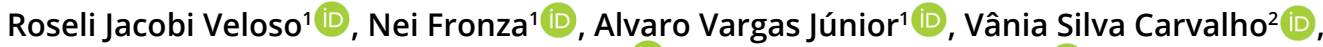 \\ Miriam Fumiko Fujinawa² ${ }^{(\mathbb{D})}$, Sheila Mello da Silveira ${ }^{1 *}(\mathbb{D})$
}

${ }^{1}$ Instituto Federal Catarinense/IFC, Campus Concórdia, Concórdia, SC, Brasil

2Instituto Federal Goiano/IFGOIANO, Campus Morrinhos, Morrinhos, GO, Brasil

${ }^{*}$ Corresponding author: sheila.silveira@ifc.edu.br

Received in March 27, 2019 and approved in September 10, 2019

\begin{abstract}
Essential oils from plants are an important alternative source of antimicrobial compounds against important pathogens for food safety. This study aimed to evaluate the in vitro antimicrobial activity of thyme essential oil (Thymus vulgaris) and to apply it in the sanitization of minimally processed arugula (Eruca sativa), aiming to increase the safety and shelf life of arugula. The in vitro antibacterial activity of the essential oil was evaluated by disc diffusion assays and determining the minimum inhibitory concentration (MIC) and minimum bactericidal concentration (MBC) against different foodborne pathogens. Thereafter, a "challenge test" was carried out to evaluate the antibacterial activity of the thyme essential oil ( $0.2 \%$ ) on the sanitization of arugula inoculated with Escherichia coli ( $3 \log \mathrm{CFU} \mathrm{mL}^{-1}$ ) compared to sodium hypochlorite (120 ppm of active chlorine). Afterwards, an experiment of applying the thyme essential oil (0.2\%) as a sanitizing agent in minimally processed arugula was carried out to evaluate the vegetable shelf life compared to sodium hypochlorite (120 ppm of active chlorine). The arugula was stored at $8^{\circ} \mathrm{C}$ for 7 days, and periodically, the number of aerobic mesophilic microorganisms, $\mathrm{pH}$ and titratable acidity were determined, and the color of the samples was evaluated. The thyme essential oil had strong antimicrobial activity in vitro against all species of bacteria tested. In the experiments in situ, the thyme essential oil (0.2\%) and sodium hypochlorite (120 ppm of active chlorine) were not efficient in eliminating the inoculated $E$. coli from minimally processed arugula, and they did not result in an extension of the shelf life of the arugula in comparison to the control $(p>0.05)$. However, the growth rate of the $E$. coli population over time on the arugula samples sanitized with the thyme essential oil ( $0.2 \%)$ was low, which indicates a positive effect of the essential oil, which may be optimized with future adjustments in the concentration and immersion time for the arugula sanitization.
\end{abstract}

Index terms: Plant extracts; vegetables; minimally processed; consumer.

\section{RESUMO}

Óleos essenciais de espécies vegetais são fontes alternativas importantes de compostos antimicrobianos no combate a patógenos de importância alimentar. O presente estudo buscou avaliar a atividade antimicrobiana in vitro do óleo essencial de tomilho (Thymus vulgaris), e aplicá-lo na sanitização de rúcula (Eruca sativa) minimamente processada, visando ao aumento da segurança e da vida útil desta hortaliça. A atividade antibacteriana in vitro foi avaliada através dos ensaios de difusão em disco, determinação da concentração mínima inibitória (CMI) e da concentração mínima bactericida (CMB) frente a diferentes espécies bacterianas de importância em alimentos. Foi realizado um teste desafio de aplicação do óleo essencial de tomilho $(0,2 \%)$ na sanitização de rúcula inoculada com Escherichia coli (3 Log UFC $\mathrm{mL}^{-1}$ ), em comparação com o hipoclorito de sódio (120 ppm de cloro ativo). Posteriormente, foi conduzido um experimento de aplicação do óleo essencial $(0,2 \%)$ como sanitizante em rúcula minimamente processada para a avaliação da vida útil desta hortaliça, armazenada a $8{ }^{\circ} \mathrm{C}$ durante 7 dias. Periodicamente, foi realizada a contagem de microrganismos aeróbios mesófilos, determinação do pH, acidez total e avaliação da cor das amostras. O óleo essencial de tomilho apresentou forte atividade antimicrobiana in vitro, frente a todas as espécies de bactérias testadas (CMls entre 0,075 e 0,62 $\mathrm{mg} \mathrm{mL}^{-1}$ ). Nos experimentos in situ, o óleo essencial de tomilho $(0,2 \%)$ e o hipoclorito de sódio (120 ppm de cloro ativo) não foram eficientes na eliminação de $E$. coli inoculada em rúcula minimamente processada, não resultando na extensão da vida útil deste produto, em comparação ao controle $(p>0.05)$. Entretanto, a taxa de incremento da população de $E$. coli ao longo do tempo foi menor nas amostras de rúcula sanitizadas com a solução à base de óleo essencial de tomilho $(0,2 \%)$, denotando um efeito positivo deste óleo essencial, que pode ser otimizado com futuras adequações de concentração e tempo de imersão durante a sanitização de rúcula.

Termos para indexação: Extratos vegetais; hortaliças; minimamente processados; consumidor. 


\section{INTRODUCTION}

The constant search for healthy food without residual chemicals which can assure the nutritional and sensorial properties, has motivated the food industry to substitute bactericides and bacteriostatic chemicals for natural products (Tanja et al., 2019). Another concerning factor is the bacterial resistance to the majority of existing antimicrobials due to the low doses of antimicrobials in food hygiene stages in addition to the residue of these products being discharged into the environment, compromising public health (Hyun, 2015). Escherichia coli, Bacillus cereus, Staphylococcus aureus, Salmonella Enteritidis, and Listeria monocytogenes, among others, are highlighted as the most important bacteria responsible for outbreaks of gastroenteritis worldwide. Other deteriorating microorganisms induce economic losses because they affect the sensory quality of minimally processed products by breaking the cell walls of the vegetable, causing stress, exposing the enzymes and substrates, and reducing the food shelf life (Siroli et al., 2015).

Aiming to identify new antimicrobial alternatives with broad spectrum activity, studies are being carried out using plant species that contain bactericidal and bacteriostatic compounds. Several plant extracts have already been tested in studies, leading to different results, and some essential oils have been used in food preservation (Khan et al., 2014; Cui et al., 2018; Hu et al. 2019). Thyme (Thymus vulgaris L.) is a plant with antimicrobial potential, and thyme essential oil is composed of phenolic components such as thymol, p-cymene, terpinene, linalool, carvacrol and eucalyptol (Pecarski et al., 2016). Cui et al. (2016) highlighted that the bactericidal effect of thyme essential oil is associated with changes that result in cellular decomposition, such as increasing cell membrane permeability, leading to intracellular leakage.

The antimicrobial effect of thyme essential oil, as in its free or encapsulated form, and its application in different food products, such as in sausages (Vafania et al., 2019), poultry meat (Lin; Liao; Cui, 2019), bakery products (Gonçalves et al. 2017), processed lettuce (Viacava et al., 2018), pineapple and melon fresh cuts (Scollard; Mcmanamon; Schmalenberger, 2016), have already been presented. However, it is important to highlight that none of these studies have evaluated the effect of thyme essential oil on minimally processed arugula thus far; therefore, this study aimed to (a) evaluate the in vitro antimicrobial activity of thyme essential oil (Thymus vulgaris L.) against gram-positive and gram-negative bacteria; (b) determine the antimicrobial effect of thyme essential oil compared to chlorine in the survival of $E$. coli inoculated on minimally processed arugula; and (c) evaluate the shelf life of sanitized arugula with a concentration of thyme essential oil compared to the sanitization with sodium hypochlorite.

\section{MATERIAL AND METHODS}

\subsection{Obtaining the essential oil}

The thyme essential oil (TEO) was commercially acquired from Ferquima Indústria e Comércio Ltda, Vargem Grande Paulista City, São Paulo State (SP), Brazil, along with its purity and origin certificate.

\subsection{Microorganisms and standardization of the inoculum}

The following important bacterial species in food were tested to evaluate the antimicrobial activity of thyme essential oil: (a) E. coli ATCC 25922; (b) Salmonella Typhimurium ATCC 14028; (b) S. aureus ATCC 25923; (c) B. cereus ATCC 11778; and (d) L. monocytogenes ATCC 19117, which were obtained from the microorganisms collection from the Laboratory of Food Microbiology of the IFC, Concórdia Campus.

The inoculum was prepared by diluting active cultures of each bacterial species in $0.9 \%$ saline solution at a concentration of approximately $10^{8} \mathrm{CFU} \mathrm{mL} \mathrm{mL}^{-1}$ compared to the standard McFarland 0.5 solution, which was determined spectrophotometrically at $625 \mathrm{~nm}$.

\subsection{Evaluation of antimicrobial activity by the disc diffusion method}

The antimicrobial activity of the essential oil (EO) was evaluated in accordance with CLSI documents M2 (CLSI, 2018a) and M100 (CLSI, 2019), with some adaptions by Silveira et al. (2012).

The suspension was diluted to approximately $10^{7}$ $\mathrm{CFU} \mathrm{mL} \mathrm{mL}^{-1}$ in saline solution, and this suspension was used to inoculate Mueller-Hinton agar plates using sterile swabs. Sterile filter paper discs (9 $\mathrm{mm}$ diameter) were impregnated with $25 \mu \mathrm{L}$ of thyme essential oil, placed on the inoculated plates and incubated at $35{ }^{\circ} \mathrm{C}$ for 18 24 hours. Commercial discs of ampicillin $(10 \mu \mathrm{g} / \mathrm{disc})$ and chloramphenicol $(30 \mu \mathrm{g} /$ disc $)$ were used as positive controls. The diameter of the inhibition zone was measured in millimeters. This test was carried out in triplicate, and the value is shown as the mean ( \pm standard deviation).

\subsection{Determination of minimum inhibitory concentration (MIC) and minimum bactericidal concentration (MBC)}

The minimum inhibitory concentration (MIC) for the bacterial species that showed susceptibility to the 
agar diffusion test was determined by the microdilution method, based on CLSI document M7 (CLSI, 2018b), adapted by Silveira et al. (2014). The EOs were diluted to a concentration of $100 \mathrm{mg} \mathrm{mL}^{-1}$ in dimethylsulfoxide (DMSO). Subsequently, successive dilution series in the range of $10 \mathrm{mg} \mathrm{mL}^{-1}$ to $0.075 \mathrm{mg} \mathrm{mL}^{-1}$ were prepared in Mueller-Hinton broth, and $100 \mu \mathrm{L}$ of each diluted solution and $5 \mu \mathrm{L}$ of the bacterial suspension were added to the wells of the microdilution plates. Sterility controls (Mueller-Hinton broth with DMSO and no inoculum addition) and growth controls (Müller-Hinton broth with DMSO and inoculum) were kept. The plates were incubated at $35^{\circ} \mathrm{C}$ for $18-24$ hours, and microbial growth was detected visually and confirmed by the addition of $20 \mu \mathrm{l}$ 2,3,5-triphenyltetrazolium chloride (TTC) at $0.5 \%(\mathrm{~m} / \mathrm{v})$, which was incubated for 1 hour at the same temperature. The test was carried out in triplicate, and the results are shown in $\mathrm{mg} \mathrm{mL}^{-1}$. The MIC was defined as the lowest EO concentration capable of completely inhibiting microbial growth.

The minimum bactericidal concentration (MBC) was determined from the plates used for the determination of MIC by the methodology described by Celiktas et al. (2007). From each well where no microbial growth occurred, $10 \mu \mathrm{L}$ was transferred to tryptone soybean agar (TSA) plates. The plates were incubated at $35{ }^{\circ} \mathrm{C}$ for 24 hours, and colony growth was verified. The analyses were carried out in triplicate, and the results are shown in $\mathrm{mg}$ $\mathrm{mL}^{-1}$. MBC was defined as the lowest concentration of the EO that completely prevented microbial growth on the plates.

\subsection{Antimicrobial activity evaluation of thyme essential oil on $E$. coli intentionally inoculated on arugula}

\subsubsection{Arugula preparation}

The arugula leaves were acquired from a local producer, whose harvest was carried out in the early morning, and refrigerated at $8^{\circ} \mathrm{C}$ until the treatment event. For the arugula leaf selection, all those with mechanical, yellowish, and small damages were removed and standardized in sizes of $10 \mathrm{~cm}$ in length. First, the arugula was rinsed in tap water to remove the large dirt, then the arugula was removed from the water and placed on a sieve for drainage. A total amount of $360 \mathrm{~g}$ of arugula was used, and for prior sanitization, the leaves were immersed in sodium hypochlorite solution at $250 \mathrm{ppm}$ (active chlorine) for $10 \mathrm{~min}$ in the proportion of $1 / 15(\mathrm{w} / \mathrm{v})$, with subsequent drainage. Finally, the arugula leaves were immersed in
$5400 \mathrm{~mL}$ of distilled water for $2 \mathrm{~min}$, repeated twice and drained.

\subsubsection{The inoculum preparation}

To activate the inoculum of $E$. coli ATCC 25922, the strain was grown on tryptone soybean agar (TSA) plates and incubated at $35^{\circ} \mathrm{C}$ for 12 to 18 hours (CLSI, 2018a), and the inoculum was prepared as previously described.

The suspension was diluted to approximately $10^{6}$ CFU mL $\mathrm{mL}^{-1}$ in $0.9 \%$ saline solution, and a suitable volume of this suspension $(4.3 \mathrm{~mL})$ was added to $5400 \mathrm{~mL}$ of distilled water to obtain a suspension containing approximately $10^{3} \mathrm{CFU} \mathrm{mL} \mathrm{mL}^{-1}$. The number of CFU $\mathrm{mL}^{-1}$ was confirmed by inoculating the suspension on methylene blue Eosin (MBE) agar and incubating at $35^{\circ} \mathrm{C}$ for 24 hours.

The arugula was immersed in the $E$. coli suspension $\left(10^{3} \mathrm{CFU} \mathrm{mL} \mathrm{mL}^{-1}\right)$ for $2 \mathrm{~min}$ while shaking gently with a glass rod, after which the excess liquid was drained. A total of $360 \mathrm{~g}$ of arugula was divided into $120 \mathrm{~g}$ portions, and each portion was submitted to different treatments.

\subsubsection{Antimicrobial treatment}

To apply the treatments, $120 \mathrm{~g}$ of arugula was immersed in a solution $(1 / 15, \mathrm{w} / \mathrm{v})$ at room temperature under gentle shaking with a glass rod for $2 \mathrm{~min}$. For the treatment with $0.2 \%$ TEO (T1), the EO was mixed with $0.5 \%$ tween 80 in a vortex to ensure the miscibility of EO in water. Subsequently, the solution was mixed with the appropriate volume, and the arugula was immersed in this solution for $2 \mathrm{~min}$ after being sieved for drainage. For the treatment with sodium hypochlorite, a solution at $120 \mathrm{ppm}$ (T2) was prepared in distilled water using the same procedure described above, and for the control treatment (C), only distilled water was used. Next, the arugula was divided into $10 \mathrm{~g}$ portions and stored in sterile plastic bags, properly identified with each treatment, in three replicates, resulting in 12 samples for each treatment. Then, the plastic bags were refrigerated at $8{ }^{\circ} \mathrm{C}$ for seven days.

\subsubsection{Enumeration of $E$. coli}

To enumerate the $E$. coli on days $0,2,5$, and 7, 90 $\mathrm{mL}$ of $0.1 \%$ peptone water was added to the samples of each treatment $(10 \mathrm{~g})$ and homogenized in a bagmixer ${ }^{\circledR}$ for 60 seconds. After homogenization, the samples were diluted and inoculated in methylene blue Eosin Agar (MBE) plates by surface sowing. The plates were incubated at $35-37^{\circ} \mathrm{C}$ for 48 hours, and then, the colonies were counted. 


\subsection{Shelf-life evaluation}

\subsubsection{Sample preparation and treatment}

To apply the treatments, $420 \mathrm{~g}$ of arugula was immersed in solution $(1 / 15 \mathrm{w} / \mathrm{v})$ at room temperature under gentle shaking with a glass rod for $2 \mathrm{~min}$. The treatments were composed of $0.2 \%$ thyme EO (T1), sodium hypochlorite at $120 \mathrm{ppm}$ (active chlorine) (T2), and distilled water (T3) prepared as described in the previous item. Subsequently, the arugula was divided into $10 \mathrm{~g}$ portions to carry out the physicochemical analyses, packed in plastic bags, properly identified, and stored at $8{ }^{\circ} \mathrm{C}$ for seven days, and analyses were carried out on days $0,2,4$, and 7 . For the microbiological analyses, the treatments were divided into $25 \mathrm{~g}$ samples, stored in sterile plastic bags, properly identified, and stored at the same temperature for seven days. Three replicates were carried out for each treatment.

\subsubsection{Total count of Aerobic Mesophilic Microorganisms}

Samples of $25 \mathrm{~g}$ were weighed in a laminar flow chamber and homogenized with $225 \mathrm{~mL}$ of peptone water $(0.1 \%)$ in a Bag-mixer ${ }^{\circledR}$ for one minute. After homogenization, successive dilutions were prepared using $0.1 \%$ peptone water as the diluent. Aliquots of $0.1 \mathrm{~mL}$ of the dilutions were inoculated on Plate Count Agar (PCA) and incubated at $35-37^{\circ} \mathrm{C}$ for 48 hours.

\subsubsection{Color evaluation}

The evaluation of the color parameters was carried out with a Konica Minolta ${ }^{\circledR}$ colorimeter, model CR 400. The color was indicated by the rectangular coordinate system $\mathrm{L}^{*}, \mathrm{a}^{*}$ and $\mathrm{b}^{*}$, according to the Comission Internatinale de L'Eclairage (CIE), in which $\mathrm{L}^{*}$ is the chroma associated with luminosity, $\mathrm{L}=0$ (black) and $\mathrm{L}=100$ (white); $\mathrm{a}^{*}$ represents the intensity of red $(+)$ or green (-); and $b^{*}$ indicates the intensity of yellow $(+)$ or blue (-) color. The arugula samples were placed on a flat surface, avoiding overlaps, and three readings were performed by marking the leaf at three points in the middle part on the adaxial side. This procedure was carried out in triplicate. Chroma is the relation among the values of $\mathrm{a}^{*}$ and $b^{*}$, in which the actual color of the analyzed product is found. Hue angle is the angle formed between $\mathrm{a}^{*}$ and $\mathrm{b}^{*}$, indicating the product color saturation. The mathematical formula $C=\sqrt{ }(a 2+b 2)$ was used to calculate chroma, and the formula $\mathrm{H}^{\circ}=\operatorname{arc} \tan \mathrm{b}^{*} / \mathrm{a}^{*}$ was used to calculate the hue angle.

\subsection{4 pH and Total Acidity (TA) Determination}

The $\mathrm{pH}$ and total acidity evaluations were carried out in triplicate in accordance with the Instituto Adolfo Lutz (IAL, 2008).

Samples of $10 \mathrm{~g}$ were weighed in a beaker, and $100 \mathrm{~mL}$ of distilled water was added. The samples were homogenized until the particles were uniformly suspended.

$\mathrm{pH}$ was determined by a benchtop digital $\mathrm{pH}$ meter, mPA 210, MS Tecnopon ${ }^{\circledR}$, under automatic temperature compensation.

To determine the acidity, the samples were titrated with $0.1 \mathrm{moL} \mathrm{L}^{-1}$ sodium hydroxide solution. Because the samples were colored or cloudy, a potentiometer was used as a tool to find the turning point. The result was indicated as a percentage of total organic acids.

\subsection{Statistics}

To evaluate the frequency distribution pattern of the data and identify the anomalous values in a $4 \mathrm{x}$ 3 factorial scheme, the descriptive statistical analysis method was adopted using software $\mathrm{R}$ version 3.5.0. The analyses were carried out by the software R, the Agricolae packages, version 1.2-8, and ExpDes pt, version 1.2.0. To test the normality, a quantile-quantile (q-q) plot was used for the normal distribution of the residues, along with the Shapiro-Wilk (normality, shapiro.test) and Bartlett tests (homogeneity, bartlett.test). The additivity of the effects of the treatments and of the blocks was found by the Tukey additivity functions (tukey.add.test). The data related to the challenge test of the inoculation of arugula with $E$. coli were compared by regression analysis. Meeting the assumptions, the analysis of variance (ANOVA) was carried out by the $\mathrm{F}$ test. For the variables in which the $F$ test was significant, the results were compared by the Tukey test $(\mathrm{p}<0.05)$.

\section{RESULTS AND DISCUSSION}

\subsection{Antimicrobial activity of thyme essential oil}

TEO showed strong antibacterial activity against all species of bacteria tested. The gram-positive bacteria $B$. cereus and L. monocytogenes showed a greater inhibition zone than the gram-negative bacteria $E$. coli and $S$. Typhimurium $(\mathrm{p}<0.05)$ (Table 1). Pecarski et al. (2016) also observed a lower activity of TEO against gram-negative bacteria. This result is explained by the fact that gram-negative bacteria have an outer membrane that prevents the entry of macromolecules and hydrophobic substances, and their interiors contain fatty acids that make 
them more resistant to antibacterials (Nazzaro et al., 2013; Picone et al., 2013). Specifically, Salmonella sp. has pumps that selectively expel toxic compounds when the bacteria are in adverse environments (Shen et al., 2014). With the exception of $S$. Typhimurium, TEO showed a better antibacterial potential against the tested microorganisms than the antibiotics ampicillin and chloramphenicol $(\mathrm{p}<$ $0.05)$.

In other in vitro studies, TEO showed antimicrobial activity against many bacterial strains. Oulkheir et al. (2017) showed that TEO had good antibacterial activity against E. coli, S. aureus, and Salmonella sp., under inhibition zones from 18 to $22 \mathrm{~mm}$. Lin, Zhu and Cui (2018) evaluated gelatin nanofibers containing TEO/ $\beta$ cyclodextrin $\varepsilon$-polylysine nanoparticles, which showed excellent antimicrobial activity against Campylobacter jejuni with a diameter inhibition zone of $25.1 \mathrm{~mm}$.

The low values in the minimum inhibitory concentration (MIC) and minimum bactericidal concentration (MBC) confirm strong antibacterial activity of TEO, with MICs from $0.075 \mathrm{mg} \mathrm{mL}^{-1}$ to $0.62 \mathrm{mg} \mathrm{mL}^{-1}$ for the five microorganisms tested (Table 2). B. cereus and E. coli showed greater inhibition by TEO $\left(0.075 \mathrm{mg} \mathrm{mL}^{-1}\right)$, but they were more resistant to its bactericidal action $(1.25$ $\left.\mathrm{mg} \mathrm{mL}{ }^{-1}\right)$. S. aureus, $S$. Typhimurium and L. monocytogenes, pathogens of great food importance, showed the same sensitivity to TEO with an MIC of $0.62 \mathrm{mg} \mathrm{mL}^{-1}$.

According to the manufacturer, the major compounds of TEO are thymol (50\%), p-cymene (30\%), and carvacrol (5\%). Thymol is a phenolic compound with effective antibacterial action, and together with other components, thymol disorganizes the cellular structure, promoting the denaturation of essential enzymes (Pereira et al., 2014). The same effect was observed by Pirbalouti et al. (2013), who identified 24 compounds in thyme, the main compounds being thymol, carvacrol, p-cymene, and s-terpinene. Similar results were reported by Santurio et al. (2014), who found that TEO showed bacteriostatic and bactericidal activity superior to thymol, the main compound of TEO, which was tested in isolation against strains of E. coli, and suggested that the antimicrobial activity shown by some essential oils resulted from the synergism of components. On the other hand, Ivanovic et al. (2013) tested isolated thyme compounds, such as thymol and p-cymene, against $E$. coli, $S$. Enteritidis, and B. cereus, and found results that showed greater antibacterial activity against $B$. cereus strains, which was the most susceptible microorganism. Siroli et al. (2015) carried out tests with different concentrations of thyme and oregano essential oils and the carvacrol isolated component and determined that the best results for the

Table 1: Antimicrobial activity of thyme essential oil found by the disc diffusion test ( $\mathrm{mm}$ ).

\begin{tabular}{cclc}
\hline MICROORGANISMS & THYME ESSENTIAL OIL & AMPICILLIN & CHLORAMPHENICOL \\
\hline S. aureus & $40.00 \pm 1.07^{\mathrm{Aab}}$ & $23.75 \pm 0.25^{\mathrm{Bbc}}$ & $27.62 \pm 0.12^{\mathrm{Ba}}$ \\
B. cereus & $45.30 \pm 10.91^{\mathrm{Aa}}$ & $18.25 \pm 0.75^{\mathrm{Cc}}$ & $26.55 \pm 0.05^{\mathrm{Ba}}$ \\
E. coli & $37.20 \pm 1.40^{\mathrm{Ab}}$ & $21.20 \pm 0.00^{\mathrm{Cbc}}$ & $28.68 \pm 0.18^{\mathrm{Ba}}$ \\
S. Typhimurium & $39.10 \pm 8.36^{\mathrm{Ab}}$ & $27.45 \pm 0.05^{\mathrm{Aab}}$ & $28.10 \pm 0.10^{\mathrm{Aa}}$ \\
L. monocytogenes & $46.50 \pm 4.05^{\mathrm{Aa}}$ & $35.00 \pm 1.22^{\mathrm{Ba}}$ & $11.15 \pm 0.05^{\mathrm{Cb}}$ \\
\hline
\end{tabular}

Inhibition zone including disc diameter, $9 \mathrm{~mm}$. Data refer to the mean of four replicates, \pm standard deviation. Inhibition degrees: 10-13.9 mm, weak; $14-18 \mathrm{~mm}$, moderate; $>18 \mathrm{~mm}$, strong. Means followed by the same capital letter in the same line and means followed by the same lowercase letter in the same column do not differ by Tukey's test $(p<0.05)$.

Table 2: Minimum inhibitory concentration (MIC) and minimum bactericidal concentration (MBC) (mg $\left.\mathrm{mL}^{-1}\right)$ of thyme essential oil against the tested microorganisms.

\begin{tabular}{ccc}
\hline BACTERIUM & $\mathrm{MIC}\left(\mathrm{mg} \mathrm{mL}^{-1}\right)$ & $\mathrm{MBC}\left(\mathrm{mg} \mathrm{mL}^{-1}\right)$ \\
\hline S. aureus & 0.62 & 0.62 \\
B. cereus & 0.075 & 1.25 \\
E. coli & 0.075 & 1.25 \\
S. Typhimurium & 0.62 & 0.62 \\
L. monocytogenes & 0.62 & 1.25 \\
\hline
\end{tabular}

The tests were carried out in triplicate, and the modal values are shown. 
MIC and MBC for the different bacterial species tested were those of carvacrol, which exhibited slightly higher inhibition of the gram-positive bacteria $L$. monocytogenes and $S$. aureus, followed by the gram-negative bacteria $E$. coli and $S$. Enteritidis.

\subsection{Antimicrobial activity evaluation of thyme essential oil on $E$. coli intentionally inoculated on arugula}

For the challenge test involving the application of the thyme essential oil on the decontamination of artificially contaminated arugula, the species $E$. coli was selected because this microorganism is frequently related to the contamination of vegetables and is prevalent in arugula. For example, in 2018 in the United States, of the three outbreaks of food poisoning associated with E. coli, two were in vegetables (CDC, 2019).

The regression analysis of the data was significant ( $\mathrm{p}<0.05$ ), resulting in the following adjustment equations: $\mathrm{Y}=$ Days $* 0.57983+2.87310, \mathrm{R} 2=0.9465$ (TEO); $\mathrm{Y}=$ Days * $0.65121+1.74828, \mathrm{R} 2=0.9941$ (sodium hypochlorite) and $\mathrm{Y}=$ Days * $0.67793+1.95724, \mathrm{R} 2$ $=0.9778$ (control). These analyses demonstrated that the growth rate of the $E$. coli population over time was lower in the arugula samples sanitized with the thyme essential oil $(0.2 \%)$ than the samples sanitized with sodium hypochlorite (120 ppm of active chlorine) and the control samples (immersed in water). Therefore, this result indicates a positive effect of the thyme essential oil on controlling the growth of the microbial population during the days the product was stored at $8^{\circ} \mathrm{C}$, taking into account the initial contamination of the samples, which was greater in the samples treated with the thyme essential oil.

The data descriptive analysis of the treatments against $E$. coli inoculated on arugula leaf samples with an initial loading of $3 \log \mathrm{CFU} \mathrm{mL} \mathrm{mL}^{-1}$ showed that there was no significant difference among the arugula samples submitted to the different treatments (Table 3), except for the arugula sanitized with sodium hypochlorite, which showed a lower number of $E$. coli $(\mathrm{p}<0.05)$ on the second day of storage.

The literature shows that positive results were found by other authors; however, in these studies, higher essential oil concentrations were used in treatments under different storage temperatures. Scollard, Mcmanamon and Schmalenberger, (2016) sprayed $0.5 \mathrm{~mL}$ of undiluted TEO on lettuce leaves contaminated with $L$. monocytogenes and observed a significant inhibitory effect. Karagözlü et al. (2011) examined the effect of mint and basil EOs at different concentrations on lettuce and purslane stored at $4^{\circ} \mathrm{C}$ inoculated with $E$. coli and $S$. Typhimurium and found that mint and basil essential oils at concentrations of $0.08 \mathrm{~mL} \mathrm{~L}^{-1}$ were the most effective against both bacteria. Walker et al. (2016) found a potential application of marjoram EO at a concentration of $0.5 \%$ in the treatment of arugula stored at $8{ }^{\circ} \mathrm{C}$.

In our experiment, the concentration of the thyme essential oil applied was $0.2 \%$, equivalent to approximately twice the MBC determined in vitro. This concentration was chosen because, through a preliminary evaluation, it was observed that this concentration could be sensorially acceptable in the case of a future commercial application.

Another factor that may have influenced the results was the contact time of the arugula leaves with the sanitizing solutions. The time of contact used was 2 min, similar to that used by other authors (Scollard; Mcmanamon; Schmalenberger, 2016; Walker et al., 2016; Siroli et al., 2015). However, this time was not effective in reducing the contamination by $E$. coli, indicating the need for a longer immersion time. In fact, by studying the in vitro thermochemical inactivation of E. coli, S. aureus and $S$. enterica Enteritidis by essential oils, Pereira et al. (2014) found that sanitizing solution based on thyme essential oil showed bactericidal activity on E. coli after 10 min of contact at $40{ }^{\circ} \mathrm{C}$.

Table 3: Effect of thyme essential oil, sodium hypochlorite, and distilled water on the survival of inoculated $E$. coli on arugula samples stored for seven days at $8{ }^{\circ} \mathrm{C}\left(\log \mathrm{CFU} \mathrm{g}^{-1}\right)$.

\begin{tabular}{|c|c|c|c|}
\hline \multirow{2}{*}{ Days } & \multicolumn{3}{|c|}{ Treatments } \\
\hline & Control & Sodium hypochlorite & TEO \\
\hline 0 & $2.00 \pm 0.3 \mathrm{AC}$ & $2.12 \pm 0.48 \mathrm{AC}$ & $3.07 \pm 0.61 \mathrm{Ac}$ \\
\hline 2 & $3.67 \pm 0.93 \mathrm{Ab}$ & $1.91 \pm 1.68 \mathrm{BC}$ & $4.88 \pm 0.68 \mathrm{Ab}$ \\
\hline 5 & $4.77 \pm 0.24 \mathrm{Ab}$ & $4.80 \pm 0.07 \mathrm{Ab}$ & $4.88 \pm 0.61 \mathrm{Ab}$ \\
\hline 7 & $6.98 \pm 0.05 \mathrm{Aa}$ & $6.45 \pm 0.49 \mathrm{Aa}$ & $7.45 \pm 0.22 \mathrm{Aa}$ \\
\hline
\end{tabular}

Means followed by the same capital letter in the same line and means followed by the same lowercase letter in the same column do not differ by Tukey's test $(p<0.05)$. 


\subsection{Shelf-life evaluation}

\subsubsection{Total count of aerobic mesophilic microorganisms}

In accordance with the results, there was no significant difference $(p<0.05)$ in the count of aerobic mesophilic microorganisms among the control and the treatments applied for the sanitization of the arugula leaves from the day of the treatments up to the fifth day of storage at $8{ }^{\circ} \mathrm{C}$ (Table 4). After seven days, the count of this microorganism group in the arugula treated with thyme essential oil was higher than in the control and the treatment with sodium hypochlorite $(\mathrm{p}<0.05)$.

Table 4: Total counts of aerobic mesophilic microorganisms (Log CFU g-1) in sanitized arugula leaves with thyme EO, sodium hypochlorite, and distilled water during the storage period at $8{ }^{\circ} \mathrm{C}$.

\begin{tabular}{cccc}
\hline & \multicolumn{3}{c}{ Treatments } \\
\cline { 2 - 4 } Days & Control & $\begin{array}{c}\text { Sodium } \\
\text { hypochlorite }\end{array}$ & TEO \\
\hline 0 & $7.15 \pm 0.24 \mathrm{Ab}$ & $5.84 \pm 1.32 \mathrm{Aa}$ & $6.59 \pm 0.62 \mathrm{Ab}$ \\
2 & $8.19 \pm 0.40 \mathrm{Aa}$ & $6.86 \pm 0.68 \mathrm{Aa}$ & $7.83 \pm 0.54 \mathrm{Aab}$ \\
5 & $8.15 \pm 0.47 \mathrm{Aa}$ & $7.89 \pm 0.88 \mathrm{Aa}$ & $8.11 \pm 0.55 \mathrm{Aa}$ \\
7 & $8.35 \pm 0.2 \mathrm{Ba}$ & $8.08 \pm 0.11 \mathrm{Ba}$ & $9.01 \pm 0.10 \mathrm{Aa}$ \\
\hline
\end{tabular}

Means followed by the same capital letter in the same line and means followed by the same lowercase letter in the same column do not differ by Tukey's test $(p<0.05)$.

The concentration of the thyme essential oil may have contributed to the greater growth of the aerobic mesophilic microorganisms after the fifth day of storage. Depending on the storage conditions, treatments, and specific characteristics of each food, the total bacterial flora may increase during storage, influencing the shelf life and causing changes in the tissues, color, taste and odor (Forsythe, 2002; Hyiun et al., 2015).

The efficacy of essential oils applied to fruit and vegetables depends on their concentration, the contact time of the vegetable with the solution containing the essential oil and the physical, chemical, and metabolic factors inherent in the product, such as fat, protein, water content, antioxidants, $\mathrm{pH}$, salt, surface morphology, ability to repel or absorb water, roughness, and microorganism characteristics (Bajpai et al., 2012; Moore-Neibel et al., 2013). However, higher concentrations of essential oils may cause undesirable organoleptic changes in food due to the strong aroma and flavor, as found by many authors in previous studies (Hyun et al., 2015; Santos et al., 2017; Scollard; Mcmanamon; Schmalenberger, 2016).

\subsection{2 $\mathrm{pH}$ and total acidity determination}

The initial $\mathrm{pH}$ of the samples varied between 6.34 and 6.44 and there was no significant variation in $\mathrm{pH}$ under different treatments in the first two days of storage (Table 5). On the fourth day of storage, the $\mathrm{pH}$ of the control increased significantly $(p<0.05)$ when compared to the treatment with sodium hypochlorite and the treatment with TEO. On the seventh day of storage, the sanitized arugula with TEO showed a higher $\mathrm{pH}$ $(p<0.05)$ than that treated with sodium hypochlorite and the control.

Table 5: $\mathrm{pH}$ values and total titratable acidity (TTA) in arugula leaves sanitized with thyme essential oil, sodium hypochlorite, and the control during the storage period at $8^{\circ} \mathrm{C}$.

\begin{tabular}{llll}
\hline & \multicolumn{3}{c}{ Treatments } \\
\cline { 2 - 4 } & Control & $\begin{array}{c}\text { Sodium } \\
\text { hypochlorite }\end{array}$ & TEO \\
\hline & \multicolumn{3}{c}{ pH } \\
0 & $6.34 \mathrm{Ac}$ & $6.43 \mathrm{Ab}$ & $6.44 \mathrm{Ac}$ \\
2 & $6.74 \mathrm{Ab}$ & $6.68 \mathrm{Ab}$ & $6.66 \mathrm{Abc}$ \\
4 & $7.87 \mathrm{Aa}$ & $7.10 \mathrm{Ba}$ & $7.00 \mathrm{Bb}$ \\
7 & $7.52 \mathrm{Ba}$ & $7.4 \mathrm{Ba}$ & $8.20 \mathrm{Aa}$ \\
\hline & & $\mathrm{TTA}$ & \\
0 & $0.50 \mathrm{Aba}$ & $0.37 \mathrm{Ba}$ & $0.57 \mathrm{Aa}$ \\
2 & $0.53 \mathrm{Aa}$ & $0.40 \mathrm{Aa}$ & $0.37 \mathrm{Ab}$ \\
4 & $0.10 \mathrm{Bb}$ & $0.27 \mathrm{Aba}$ & $0.37 \mathrm{Ab}$ \\
7 & $0.20 \mathrm{Ab}$ & $0.23 \mathrm{Aa}$ & $0.27 \mathrm{Ab}$ \\
\hline
\end{tabular}

Means followed by the same capital letter in the same line and means followed by the same lowercase letter in the same column do not differ by Tukey's test $(p<0.05)$.

Similar $\mathrm{pH}$ values were found by Jardina et al. (2017) until the sixth day of storage of sanitized arugula cultivars with sodium hypochlorite refrigerated at $8{ }^{\circ} \mathrm{C}$.

$\mathrm{pH}$ values between 6.5 and 7.5 are the most favorable for the development of most microorganisms, 
both deteriorating and pathogenic. The deterioration of food of plant origin by microorganisms leads to an increase in $\mathrm{pH}$ and a consequent decrease in acidity (Franco; Landgraf, 2003).

In general, the total acidity reflected the $\mathrm{pH}$ changes that occurred during the storage period of the arugula, that is, while the $\mathrm{pH}$ increased during storage, the values of acidity decreased, which was expected because of the natural process of vegetable deterioration. From the second day of storage, the total acidity values decreased significantly for all treatments until the last day of storage.

Higher $\mathrm{pH}$ values and lower acidity values are indicators of deteriorating foods (Chitarra; Chitarra, 2005), and the total acidity is directly linked to vegetable conservation. Since it measures organic acids, lower acidity values indicate inferior vegetable quality (Costa et al., 2007).

\subsubsection{Color evaluation}

The $\mathrm{L}^{*}, \mathrm{a}^{*}$, and $\mathrm{b}^{*}$ instrumental parameters were measured to find possible color changes during the arugula shelf life (Table 6). In this sense, the $\mathrm{L}^{*}$ parameter, which indicates the luminosity (or white content of a sample), was analyzed individually. Regarding this parameter, a significant difference $(p<0.05)$ was found in the TEO treatment at the end of shelf life, which was 42.91 , compared to 46.85 and 49.26 for the control and sodium hypochlorite, respectively. This fact is most likely due to the antioxidant effect, a behavior that is widely known in essential oils (Almela et al., 2013; Khan et al., 2014; Runyoro et al., 2010).

The coordinates of a* (green/red) did not show significant differences between treatments during the storage period. The $b^{*}$ chromatic coordinate (blue/ yellow) showed a significant difference $(\mathrm{p}<0.05)$ in the values found by the treatment with the thyme essential oil on the last day of shelf life, which was 29.34, compared to 34.9 for the control and sodium hypochlorite, 36.28. In this work, it was found that minimally processed arugula treated with TEO showed lower values for $\mathrm{L}^{*}$, which indicates the maintenance of the appearance of a "fresh" product, similar to the green characteristic color of arugula. Fruit and vegetables in the postharvest period deteriorate rapidly by increasing the respiration rate and increasing ethylene production, consequently activating/initiating a change in reactions such as nutrient losses and color alteration (Bem-Fadhel et al., 2017).
Table 6: Averages for the color physical parameter with $L^{*}, b^{*}$, and $a^{*}$ individual values in the minimally processed arugula leaves.

\begin{tabular}{cccc}
\hline Days & \multicolumn{3}{c}{ Treatments } \\
\cline { 2 - 4 } & Control & TEO & $\begin{array}{c}\text { Sodium } \\
\text { hypochlorite }\end{array}$ \\
\hline & \multicolumn{3}{c}{ L* $^{*}$} \\
0 & $45.08 \mathrm{Aa}$ & $42.74 \mathrm{Ba}$ & $45.27 \mathrm{Aa}$ \\
2 & $46.28 \mathrm{Aa}$ & $41.60 \mathrm{Aab}$ & $46.03 \mathrm{Aa}$ \\
4 & $38.12 \mathrm{Ab}$ & $35.78 \mathrm{Ab}$ & $34.31 \mathrm{Ab}$ \\
7 & $46.85 \mathrm{Aba}$ & $42.91 \mathrm{Ba}$ & $49.26 \mathrm{Aa}$ \\
& & $a^{*}$ & \\
0 & $-28.28 \mathrm{Aa}$ & $-17.36 \mathrm{Aa}$ & $-19.57 \mathrm{Ab}$ \\
2 & $-20.43 \mathrm{Aa}$ & $-15.97 \mathrm{Aa}$ & $-20.03 \mathrm{Ab}$ \\
4 & $-14.02 \mathrm{Ba}$ & $-13.04 \mathrm{Aa}$ & $-13.83 \mathrm{Ba}$ \\
7 & $-20.52 \mathrm{Aa}$ & $-18.94 \mathrm{Aa}$ & $-20.77 \mathrm{Ab}$ \\
& & $\mathrm{b} *$ & \\
0 & $27.08 \mathrm{Ab}$ & $30.21 \mathrm{Ab}$ & $30.01 \mathrm{Ab}$ \\
2 & $32.12 \mathrm{Ab}$ & $31.74 \mathrm{Ab}$ & $31.04 \mathrm{Ab}$ \\
4 & $17.41 \mathrm{Aa}$ & $16.19 \mathrm{Aa}$ & $17.24 \mathrm{Aa}$ \\
7 & $34.94 \mathrm{Bb}$ & $29.34 \mathrm{Ab}$ & $36.28 \mathrm{Bc}$ \\
\hline
\end{tabular}

Means followed by the same capital letter in the same line and means followed by the same lowercase letter in the same column do not differ by Tukey's test $(p<0.05)$.

\section{CONCLUSIONS}

The thyme essential oil showed strong antimicrobial activity in vitro against all species of bacteria tested.In the in situ experiments, the thyme essential oil $(0.2 \%)$ and sodium hypochlorite (120 ppm) were not efficient in eliminating the inoculated $E$. coli in minimally processed arugula ( $\left.3 \log _{\mathrm{CFU} \mathrm{g}}{ }^{-1}\right)$ or decreasing the natural microbiological contamination of arugula, and they did not result in an extension of this product's shelf life. Most likely, the concentrations used and the contact time of the sanitizing solutions with the arugula were not enough to promote the desired decontamination. In spite of that, according to the regression analysis performed, the growth rate of the E. coli population over time was lower in the arugula samples sanitized with the thyme essential oil $(0.2 \%)$, which indicates a positive effect of the TEO, which may be optimized with future adjustments in the concentration and immersion time for the arugula sanitization. 


\section{REFERENCES}

ALMELA, C. E. M. O. M. D et al. Influence of minimally processed grapes washing with lemon essential oil. Food Research Journal. 21(5):1851-1857. 2013.

BAJPAI, V. K. et al. Control of Salmonella in foods by using essential oils: A review. Food Research International, (45):722-734, 2012.

BEM-FADHEL, V. et al. Active edible coating and y-irradiation as cold combined treatments to assure the safety of broccoli florets (Brassica oleracea L.). International Journal of Food Microbiology, 241:30-34, 2017.

CENTERS FOR DISEASE CONTROL AND PREVENTIONCDC [National Center for Emerging and Zoonotic Infectious Diseases (NCEZID), Division of Foodborne, Waterborne, and Environmental Diseases (DFWED)]. Reports of E. coli Outbreak Investigations from 2018. 2018. Available in: <https://www.cdc.gov/ecoli/surv2016/index.html> Access in: June, 26, 2019.

CELIKTAS, O. Y. et al. Antimicrobial activities of metanol extracts and essential oils of Rosmarinus officinalis, depending on location and seasonal variations. Food Chemistry, 100(2):553-559, 2007.

CHITARRA, M. I. F.; CHITARRA, A. B. Pós-colheita de frutos e hortaliças: Fisiologia e Manuseio. 2.edição revisada e ampliada Lavras: Editora UFLA, 783p. 2005.

CLINICAL AND LABORATORY STANDARDS INSTITUTE CLSI. Performance Standards for Antimicrobial Disk Susceptibility Tests. 13th ed. CLSI standard M02. Wayne, PA: Clinical and Laboratory Standards Institute; 2018a, 19p.

CLINICAL AND LABORATORY STANDARDS INSTITUTE - CLSI. Methods for Dilution Antimicrobial Susceptibility Tests for Bacteria that Grow Aerobically. $11^{\text {th }}$ ed. CLSI standard M07. Wayne, PA: Clinical and Laboratory Standards Institute; 2018b, 13p.

CLINICAL AND LABORATORY STANDARDS INSTITUTE - CLSI. Performance Standards for Antimicrobial Susceptibility Testing. 29th ed. CLSI supplement M100. Wayne, PA: Clinical and Laboratory Standards Institute; 2019, 25p.

COSTA, J. M. C. et al. Comparação dos parâmetros físico-químicos e químicos de pós alimentícios obtidos de resíduos de abacaxi. Revista Ciência Agronômica, 38(2):228-232, 2007.

$\mathrm{CUI}, \mathrm{H}$. et al. Enhancing the antibacterial activity of thyme oil against Salmonella on eggshell by plasma-assisted process. Food Control, 70:183-190, 2016.
$\mathrm{CUI}, \mathrm{H}$. et al. Antimicrobial mechanism of clove oil on Listeria monocytogenes. Food Control, 94:140-146, 2018.

FORSYTHE, S. J. Microrganismos causadores de doenças de origem alimentar: Microbiologia de segurança alimentar. Artmed, p.164-168, 2002.

FRANCO, F.; LANDGRAF, M. Microbiologia dos Alimentos. Atheneu, 2003. 196p.

GONÇALVES, N. D. et al. Encapsulated thyme (Thymus vulgaris) essential oil used as a natural preservative in bakery product. Food Research International, 96:154-160, 2017.

HU, W. et al. Antibacterial activity and mechanism of Litsea cubeba essential oil against methicillin-resistant Staphylococcus aureus (MRSA). Industrial Crops and Products, 130: 34-41, 2019.

HYUN, J. E. et al. Preservative effectiveness of essential oils in vapor phase combined with modified atmosphere packaging against spoilage bacteria on fresh cabbage. Food Control, 51:307-313, 2015.

INSTITUTO ADOLFO LUTZ- IAL. Métodos físico-químicos para análise de alimentos: Normas Analíticas do Instituto Adolfo Lutz. 4a ed. São Paulo, SP, Brasil: Instituto Adolfo Lutz, 1020 p. 2008.

IVANOVIC, J. et al. Evaluation and improvement of antioxidant and antibacterial activities of supercritical extracts from clove buds. Journal of Functional Foods, 5(1):416-423, 2013.

JARDINA, L. L. et al. Comportamento fisiológico pós-colheita de cultivares de rúcula minimamente processadas. Revista Trópica: Ciências Agrárias e Biológicas, 10(1):50-64, 2017.

KARAGOZLÜ, N. et al. Determinacion of antimicrobial effect of mint and basil essential oils on survival of E. coli 0157:H7 and S. typhimurium in fresh-cut lettuce and purslane. Food Control, 22(12):1851- 1855, 2011.

KHAN, A. et al. Nanocellulose-based composites and bioactive agents for food packaging. Critical Reviews in Food Science and Nutrition, 54(2):163-174, 2014.

LIN, L.; LIAO, X.; CUI, H. Cold plasma treated thyme essential oil/silk fibroin nanofibers against Salmonella typhimurium in poultry meat. Food Packaging and Shelf Life, 21:100337, 2019.

LIN, L.; ZHU, Y.; CUI, H. Electrospun thyme essential oil/ gelatin nanofibers for active packaging against Campylobacter jejuni in chicken. LWT-Food Science and Technology, 97: 711-718, 2018. 
MOORE-NEIBEL, K. et al. Antimicrobial activity of oregano oil against antibiotic- resistant Salmonella enterica on organic leafy greens at varying exposure times and storage temperatures. Food Microbiology, 34(1):123-129, 2013.

NAZZARO, F. et al. Effect of essential oils on pathogenic bacteria. Pharmaceuticals, 6(12):1451-1474, 2013.

OULKHEIR, S. et al. Antibacterial Activity of Essential Oils Extracts from Cinnamon, Thyme, Clove and Geranium Against a Gram Negative and Gram Positive Pathogenic Bacteria. Journal of Diseases and Medicinal Plants, 3(2-1):1-5, 2017.

PECARSKI, D. et al. Chemical compositions and antimicrobial activities of oregano and thyme essential oils. Bulgarian chemical communications, 48(4):678-683, 2016.

PEREIRA, A. et al. Inativação termoquímica de Escherichia coli, Staphylococcus aureus e Salmonella enterica Enteritidis por óleos essenciais. Ciência Rural, 44(11):2022-2028, 2014.

PICONE, G. et al. Evaluation of the effect of carvacrol on the Escherichia coli 555 metabolome by using $\mathrm{H}$ NMR spectroscopy. Food Chemistry, 141(4):4367-4374, 2013.

PIRBALOUTI, A. G. et al. Essential oil compositions, antibacterial and antioxidant activities of various populations of Artemisia chamaemelifolia at to phenological stages. Revista Brasileira de Farmacognosia, 23:861-869, 2013.

RUNYORO, D. et al. Chemical composition and antimicrobial activity of the essential oils of four Ocimum species growing in Tanzania. Food Chemistry, 119(1):311-316, 2010.

SANTOS, R. R. et al. Use of essential oil in active food packaging: Recent advances and future trends. Trends in Food Science \& Technology, 61:132-140, 2017.

SANTURIO, D. F. et al. Antimicrobial activity of the essential oil of thyme and of thymol against Escherichia coli strains. Acta Scientiae Veterinariae, 42:1-4, 2014.

SCOLLARD, J.; MCMANAMON, O.; SCHMALENBERGER, A. Inhibition of Listeria monocytogenes growth on fresh cut produce with thyme essential oil and essential oil compound verbenone. Postharvest Biology and Technology, 120:61-68, 2016.

SHEN, Y. et al. High Vanillin tolerance of an evolved Saccharomyces cerevisiae strain owing to its enhanced vanillin reduction and antioxidative capacity. Journal in Microbiology Biotechnology, 41(11):1637-45, 2014.

SILVEIRA, S. M. et al. Composição química e atividade antimicrobiana de óleos essenciais de plantas selecionadas cultivadas no Sul do Brasil contra micro-organismos patogênicos e deteriorantes de alimentos. Ciência Rural, 422(7):1300-1306, 2012.

SILVEIRA, S. M. et al. Chemical composition and antibacterial activity of Laurus nobilis essential oil towards foodborne pathogens and its application in fresh Tuscan sausage stored at $7^{\circ} \mathrm{C}$. Lebensmittel Wissenschaft Technologie Food Science Technology, 59(1):86-93, 2014.

SIROLI, L. et al. Natural antimicrobials to prolong the shelflife of minimally processed lamb's lettuce. Postharvest Biology and Technology, 103:35-44, 2015.

TANJA, D. A. et al. Economic and Environmental Context of Organic Agriculture and Farms in Serbia - Case Stud. Fresenius environmental bulletin, 28(1):87-92, 2019.

VAFANIA, B. et al. Nanoencapsulation of thyme essential oil in chitosan-gelatin nanofibers by nozzle-less electrospinning and their application to reduce nitrite in sausages. Food and Bioproducts Processing, 116:240-248, 2019.

VIACAVA, G. E. et al. Effect of free and microencapsulated thyme essential oil on quality atributes of minimally processed lettuce. Postharvest Biology and Technology, 145:125133, 2018.

WALKER, J. F. et al. Antimicrobial activity of marjoram (Origanum majorana) essential oil against the multidrug-resitant Salmonella enterica serovar schwarzengrund inoculated in vegetables from organic farming. Journal of Food Safety, 36:489-496, 2016 